\title{
EFEKTIVITAS EKSTRAK BUNGA KENANGA (Cananga odorata) SEBAGAI BAHAN ANESTESI PADA TRANSPORTASI BENIH NILA MERAH (Oreochromis sp.) TANPA MEDIA AIR
}

\section{The Effectiveness of Cananga Flower (Cananga odorata) as an Anesthetic Material On Trnsportation Red Tilapia Fry (Oreochromis sp.) Withoutt Water Media}

\author{
Maryani, Eko Efendi dan Deny Sapto Chondro Utom \\ Program Studi Budidaya Perairan, Jurusan Perikanan dan Kelautan \\ Fakultas Pertanian, Universitas Lampung \\ Jl. Prof Dr Ir. Sumantri Brojonegoro No.1, Gedong Meneng, Rajabasa, Bandar Lampung, Lampung \\ Email : Maryadiy665@gmail.com
}

Diserahkan tangga 16 Februari 2018, Diterima tanggal 19 April 2018

\begin{abstract}
ABSTRAK
Bunga kenanga (Cananga odorata) mengandung senyawa eugenol yang mempunyai sifat anestesi, sehingga berpotensi sebagai bahan anestesi dalam transportasi ikan. Penelitian ini bertujuan untuk mengetahui pengaruh lama waktu transportasi terhadap survival rate (SR) benih nila merah pada uji simulasi transportasi. Metode penelitian yang digunakan untuk menentukan nilai konsentrasi adalah analisis probit. Rancangan penelitian yang digunakan adalah rancangan acak lengkap (RAL) dengan selang kepercayaan 95\%. Hasil analisis probit uji $\mathrm{LC}_{50}-96$ jam nilai yang didapat yaitu 93,97 ppm, dan analisis probit pada uji $\mathrm{EC}_{50}-1$ jam yaitu $61,40 \mathrm{ppm}$. Uji transportasi menunjukan nilai kelangsungan hidup tertinggi terdapat pada perlakuan 1 jam dengan nilai rata-rata mencapai $91,1 \%$. Hasil penelitian menunjukan bahwa perbedaan waktu berpengaruh nyata terhadap kelangsungan hidup benih nila merah.
\end{abstract}

Kata kunci: Bunga kenanga, anestesi, ikan nila, tansportasi sistem kering

\section{ABSTRACT}

The Flower kenanga (Cananga odorata) contains euganolic substances that have trait anesthetic, therefore potentially as anesthesia for fish transportation. This research is intended to identify the effects of the transport duration towards the survival rate of seed red tilapia using a transportation simulation. The scientific method used in this research to determine the level of concentration used probit analysis. The design that was used was the complete random design (RAL) with a confidence interval of $95 \%$. The analysis result of test probit LC $C_{50}-96$ hours was 93,97 ppm, and the analysis result of test probit EC $50-1$ hour was 61,40 ppm. The transportation test showed that the highest life sustainability was achieved during the 1-hour test with an average value of 91,1\%. The results of the experiment showed that difference in duration has a real effect on life sustainability of the seed red tilapia.

Keywords: Cananga odorata, anesthetic, tilapia red, dry transport system.

\section{PENDAHULUAN}

Transportasi merupakan bagian penting dari usaha ikan komersial. Transportasi benih nila merah (Oreochromis niloticus) yang dilakukan selama ini menggunakan media pengangkutan air atau sistem basah yang memiliki kelemahan dan sangat beresiko menimbulkan stres, cedera fisik, bahkan kematian saat proses transportasi dilakukan..Kematian ikan disebabkan oleh penurunan kualitas air media pengiriman akibat aktifitas metabolisme dan respirasi ikan. Selain itu kematian ikan juga dapat ditimbulkan karena menurunnya kadar oksigen didalam wadah, meningkatnya kadar amonia dan $\mathrm{CO} 2$,serta kebocoran wadah pengemasan ikan ketika proses transportasi dilakukan.

Transportasi sistem kering pada prinsipnya adalah transportasi dengan mengkondisikan ikan dalam keadaan metabolisme dan respirasi rendah sehingga daya tahan tubuh di luar habitat hidupnya lebih tinggi (Pramono, 2002). Sistem transportasi ikan hidup tanpa media air (sistem kering) saat ini semakin berkembang terutama untuk crustacea, tetapi untuk ikan terutama benih nila merah masih merupakan hal yang baru dan belum berkembang di masyarakat. Teknik ini perlu dikembangkan terutama untuk tujuan ekspor karena dapat mengurangi berat pengiriman dan resiko kebocoran pada saat pengiriman. Faktor-faktor yang perlu diperhatikan dalam transportasi ikan hidup tanpa media air adalah jenis media pengemas, perlakuan ikan sebelum dikemas (imotilisasi atau hibernasi), suhu media selama pengangkutan, dan kemungkinan penggunaan anti metabolit (zat anestesi) (Fauziah $d k k, 2010$ ).

Anestesi diperlukan untuk ikan dalam transportasi sistem kering, kegiatan penelitian, diagnosa penyakit, dan pembedahan. Anestesi bertujuan untuk menurunkan seluruh aktivitas ikan, terutama untuk jenis ikan dari kelompok elasmobranci, dan penurunan metabolisme (Pramono, 2002). Anestesi ikan dapat dilakukan dengan cara memberikan bahan pembius pada benih ikan, salah satunya penelitian yang pernah dilakukan untuk membius ikan yaitu dengan menggunakan

(C) Copyright by Saintek Perikanan (Indonesian Journal of Fisheries Science and Technology), ISSN : 1858-4748 
ekstrak akar tuba (Derris elliptica ) (Irawan, 2014). Saat ini bahan anestesi ikan yang banyak dikenal oleh masyarakat adalah bahan anestesi kimia sintetis, seperti MS-222, benzocaine, metomidate, phenoxyethanol, quinaldine, dan chinaldine. Sedangkan bahan alami yang selama ini biasa digunakan dalam teknik anestesi adalah es, minyak cengkeh, ekstrak tembakau, ekstrak mengkudu, ekstrak bunga kamboja, ekstrak pepaya, dan ekstak bunga kenanga yang penulis gunakan ini

Menurut Moelyono (2007) bunga kenanga mengandung beberapa senyawa eugenol seperti eugenol, isoeugenol, metal eugenol dan metil iso-eugenol. Eugenol dalam bidang pengobatan digunakan sebagai bahan antiseptik dan anestesi (Rumondang, 2004). Penelitian ini bertujuan untuk Mengetahui pengaruh lama waktu transportasi terhadap survival rate (SR) benih nila merah pada uji simulasi transportasi tanpa media air.

\section{METODE PENELITIAN}

Penelitian dilakukan pada Januari 2017 sampai Februari 2017 bertempat di Laboraturium Budidaya Perikanan Universitas Lampung. Bahan yang digunakan dalam penelitian adalah ekstrak bunga kenanga (Cananga odorata) yang berbentuk serbuk, akuades dan benih ikan nila merah (Oreochromis niloticus) berukuran $3-5 \mathrm{~cm}$ yang dibeli dari balai benih didaerah Bandar Lampung.

Rancangan penelitian ini menggunakan Rancangan Acak Lengkap (RAL) yang terdiri dari penelitian pendahuluan dan penelitian utama dengan masing-masing perlakuan tiga kali ulangan yaitu penelitian penentuan ambang konsentrasi (ambang batas atas dan ambang batas bawah) 48 jam, penelitian penentuan nilai $\left(\mathrm{LC}_{50}-96\right.$ jam), penentuan nilai (EC $\left.\mathrm{E}_{50}-1 \mathrm{jam}\right)$, dan uji simulasi transportasi dengan lama waktu transportasi yang digunakan yaitu 1, 2, dan 3 jam.

Prosedur penelitian terdiri dari dua tahap yaitu tahap pendahuluan dan penelitian utama. Penelitian pendahuluan berupa penentuan ambang konsentrasi (ambang batas atas dan ambang batas bawah). Penelitian utama berupa penentuan median lethal concentration $\left(\mathrm{LC}_{50}\right)$ yang dilakukan dengan uji toksisitas menggunakan metode probit (Hendri $\boldsymbol{d} \boldsymbol{k} \boldsymbol{k}, \mathbf{2 0 1 0}$ ), dan uji $\left(E_{50}\right)$ yang kemudian dilanjutkan dengan uji simulasi transportasi dengan menggunakan sistem kering (tanpa media air) dengan bahan anestesi ekstrak bunga kenanga.

Penelitian ini memiliki beberapa tahapan, yaitu persiapan alat dan bahan, persiapan ekstrak dengan pelarut aquades, Analisis Probit, pengujian pada ikan, uji transportasi, dan pemeliharaan benih nila merah.

\section{Persiapan Pembuatan Ekstak}

Pada tahap ini ada beberapa hal yang dilakukan yaitu menyiapkan alat dan bahan yang dibutuhkan untuk ekstraksi. Alat yang digunakan adalah gelas ukur, 3 toples, 3 pengaduk, kain penyaring. Bahan yang digunakan adalah serbuk bunga kenanga dan aquades sebagai pelarutnya, dalam hal ini ekstak yang akan dibuat yaitu berupa larutan.

\section{Persiapan Ekstrak dengan Pelarut Aquades}

1. Menimbang bubuk bunga kenanga tiap $1000 \mathrm{mg}$ untuk 11 aquades

2. Diaduk agar tercampur merata dengan sempurna
3. Hasil campuran disaring menggunakan kain saring untuk memisahkan ekstrak air dengan kotoran sisa dari bahan baku

4. Ekstrak air yang didapat digunakan sebagai larutan stok

5. Larutan stok dibuat dengan cara mengencerkan ekstrak dengan pelarut aquades dengan konsentrasi interval logaritmik 100, 10, 1, 0,1, dan 0,01 ppm pada 51 air. Untuk membuat larutan stok tersebut banyaknya pelarut dan ekstrak yang digunakan adalah $\mathrm{mg} / \mathrm{l}$.

Dari konsentrasi interval logaritmik dibutuhkan (500, 50, 5, 0,5, dan 0,05 ml) larutan stok untuk dilarutkan ke akuarium dengan masing-masing volume air 51 untuk satu kali perlakuan.

\section{Penelitian Pendahuluan \\ Persiapan Wadah}

Wadah uji berupa akuarium berukuran 40x30x30 cm yang sudah bersih dan kering. Akuarium yang digunakan pada uji pendahuluan adalah 15, masing-masing berisi air 51 . Selanjutnya akuarium diaerasi selama 24 jam, untuk meningkatkan konsentrasi oksigen dalam air.

\section{Persiapan Hewan Uji}

Sebelum melakukan uji pendahuluan, ikan nila diaklimatisasi kedalam wadah uji selama 24 jam agar tidak setres dan tanpa diberi makan atau dipuasakan. Ikan yang digunakan 15 ekor dengan ukuran $3-5 \mathrm{~cm}$ untuk setiap akuarium.

\section{Pelaksanaan Uji Pendahuluan}

Pada uji pendahuluan ini terdapat 15 perlakuan dimana terdapat 5 konsentrasi dan 3 ulangan. Konsentrasi yang digunakan yaitu menggunakan konsentrasi secara logaritmik. Konsentrasi yang digunakan untuk masing-masing perlakuan menggunakan rumus logaritmik yaitu 100, 10, 1, 0,1, dan 0,01 ppm pada 51 air. Setiap perlakuan diulang sebanyak 3 kali. Selama percobaan benih ikan nila tidak diberi makan dan air media diaerasi. Amati selama 48 jam yang dihitung dengan selang waktu aritmatika yaitu $3 ; 6 ; 12 ; 24$; dan 48 jam. Benih ikan nila yang mati pada setiap perlakuan dicatat jumlahnya dan dikeluarkan dari wadah percobaan.

Uji pendahuluan ini bertujuan untuk menentukan ambang batas atas dan ambang batas bawah. Konsentrasi ambang batas atas adalah konsentrasi terendah dari bahan uji yang dapat menyebabkan semua ikan uji mati pada waktu pemaparan 24 jam. Sedangkan konsentrasi ambang batas bawah adalah konsentrasi tertinggi dari bahan uji yang dapat menyebabkan semua ikan uji hidup setelah waktu pemaparan 48 jam.

\section{Penelitian Utama \\ Persiapan Wadah}

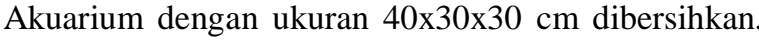
Akuarium yang digunakan pada uji utama ini yaitu 15 buah dan diisi air sesuai konsentrasi dan pelarut yang didapat pada uji pendahuluan.

\section{Persiapan Hewan Uji}

Sebelum melakukan uji utama, benih ikan nila diaklimatisasi kedalam wadah uji selama 24 jam agar tidak setres dan dipuasakan atau tanpa diberi makan. Ikan yang 
digunakan 15 ekor dengan ukuran 3-5 cm untuk setiap akuarium dengan berat rata-rata ikan uji 0,5 g/ekornya, ikan diambil dalam keadaan hidup dan sehat.

\section{Pelaksanaan Uji Utama}

Pada uji utama, konsentrasi ditentukan dari ambang batas atas dan ambang batas bawah dari uji pendahuluan. Rumus yang digunakan untuk menentukan konsentrasi pada uji utama ini dapat dilihat dibawah ini. Uji ini dilakukan selama 96 jam untuk menentukan $\mathrm{LC}_{50}-96$ jam dari ekstrak bunga kenanga dengan pelarut aquades. Diamati selama 96 jam yang dihitung dengan menggunakan selang aritmatika yaitu $3 ; 6 ; 12$; 24; 48 dan 96 jam. Data yang diambil pada uji utama ini yaitu mortalitas benih ikan nila dan kualitas air saat pengujian.

Perhitungan kisaran konsentrasi yang digunakan dalam uji toksisitas dihitung berdasarkan rumus berikut :

$$
\begin{gathered}
\log \frac{N}{n}=K\left(\log \frac{a}{n}\right) \\
\frac{a}{n}=\frac{\mathrm{b}}{a}=\frac{\mathrm{c}}{b}=\frac{d}{c}=\frac{\mathrm{e}}{d}=\frac{\mathrm{N}}{e}
\end{gathered}
$$

Keterangan :

$\mathrm{N}$ : Konsentrasi ambang atas

$\mathrm{n}$ : Konsentrasi ambang bawah

$\mathrm{K}$ : Jumlah konsentrasi yang diuji (misal. 5; a, b, c, d, e)

a : Konsentrasi yang paling kecil dari deret yang ditentukan

Penentuan nilai konstanta a, b, c, d, dan e dilakukan dengan mengambil ekstrak dari larutan stok. Untuk memperoleh konsentrasi yang diinginkan digunakan rumus :

Keterangan :

$$
\mathrm{V}_{1} \cdot \mathrm{M}_{1}=\mathrm{V}_{2} \cdot \mathrm{M}_{2}
$$

$\mathrm{V}_{1}$ : Volume larutan stok yang akan digunakan

$\mathrm{M}_{1}$ : Konsentrasi larutan stok

$\mathrm{V}_{2}$ : Volume yang diuji

$\mathrm{M}_{2}$ : Konsentrasi yang diinginkan

Pengamatan pada uji utama dilakukan setelah 96 jam. Pada uji utama ini data yang diambil adalah mortalitas dari hewan uji pada setiap perlakuan.

\section{Penetapan Nilai Konsentrasi Efek (EC 50 -1 jam)}

Penentuan $\mathrm{EC}_{50}-1$ jam uji toksisitas ini menggunakan metode analisis probit (Hendri $d k k, 2010) . \mathrm{EC}_{50}-1$ jam diperoleh dari hubungan nilai logaritma konsentrasi bahan uji dan nilai probit dari persentase mortalitas hewan uji merupakn fungsi linear dengan rumus :

Keterangan :

$$
\mathrm{Y}=\mathrm{a}+\mathrm{bx}
$$

Y : Nilai probit mortalitas

A : Konstanta

B : Slope/ kemiringan

$\mathrm{X}$ : Logaritma konsentrasi bahan uji

$\mathrm{EC}_{50}$-1 jam diperoleh dari anti log $\mathrm{m}$, dimana $\mathrm{m}$ merupakan logaritma konsentrasi bahan toksik pada $\mathrm{Y}=5$, yaitu nilai probit $50 \%$ hewan uji, sehingga rumus regresi menjadi

$$
\mathbf{M}=\frac{5-a}{b}
$$

Dengen nilai a dan b diperoleh berdasarkan rumus sebagai berikut :

$$
\begin{aligned}
\mathbf{b} & =\frac{\sum 5 X Y \frac{1}{n}\left(\sum X \sum Y\right)}{\sum x^{2} \frac{1}{n}\left(\sum X\right)^{2}} \\
a & =\frac{1}{n}\left(\sum Y-b \sum X\right)
\end{aligned}
$$

\section{Keterangan :}

$\mathrm{n}$ : banyaknya perlakuan

$\mathrm{m}$ : nilai $\mathrm{X}$ pada $\mathrm{Y}=5$

\section{Penentuan Konsentrasi Efek (EC50-1 jam)}

1. Persiapan akuarium sebanyak 9 buah disiapkan, dicuci, dan masing-masing diisi air sebanyak 51 kemudian diaerasi selama 24 jam.

2. Ekstrak bunga kenanga ditambahkan pada media sebagai bahan anestesi sebanyak nilai konsentrasi pada uji toksisitas dan diaduk merata serta diulang sebanyak tiga kali.

3. Benih ikan nila dimasukkan dalam akuarium dengan padat tebar 15 ekor/akuarium dan dicatat waktu pingsannya.

4. Pengamatan dan pencatatan jumlah benih ikan nila yang pingsan pada setiap perlakuan, dilakukan pada menit ke-5, $10,15,20,25,30,35,40,45,50,55$, dan 60. Indikator ikan yang pingsan ditandai dengan kondisi benih yang bergerak lambat, ikan berdiam di dasar dan operkulum bergerak lemah. Selanjutnya benih ikan nila dipindahkan ke wadah yang berisi air bersih.

\section{Uji Simulasi Transportasi}

Simulasi transportasi dilakukan dengan menggunakan kendaraan roda dua (motor) dengan asumsi bahwa jarak tempuh dihitung sama dengan waktu transportasi saat dalam perjalanan seminimal mungkin. Simulasi transportasi dilakukan selama tiga waktu pengamatan yaitu 1, 2, dan 3 jam.

\section{Persiapan Wadah Anestesi Benih Nila Merah}

Wadah yang digunakan adalah akuarium berukuran 30x20x20 cm. wadah dibersihkan terlebih dahulu dengan air bersih dan diisi air sebanyak $5 \mathrm{l}$. Wadah pengangkut ikan yaitu kotak styrofoam yang biasa digunakan dalam pengemasan ikan disiapkan, media pendingin menggunakan limbah serbuk gergaji yang berasal dari kayu yang diperoleh dari pengrajin kayu di Bandar Lampung. Serbuk gergaji dibersihkan terlebih dahulu dengan cara pengayakan, perendaman dalam air tawar selama 24 jam lalu dibilas, kemudian dijemur hingga kering. Serbuk gergaji yang telah kering didinginkan sesuai suhu penyimpanan.

\section{Anestesi Benih Nila Merah}

Sebelum anestesi dilakukan, benih nila merah ditimbang terlebih dahulu untuk mengetahui berat awal pada ikan. Perlakuan anestesi ikan dilakukan dalam satu wadah yang sama. Bahan anestesi dengan nilai konsentrasi yang paling efektif yang didapat pada uji $\mathrm{EC}_{50-1}$ jam ditambahkan pada wadah yang telah diisi air dan diaduk merata. Ikan uji dimasukan kedalam wadah dan diamati kecepatan pingsannya. Parameter tersebut mengukur reaksi benih nila merah mulai dari pemberian bahan anestesi sampai benih nila merah tersebut pingsan, yang biasanya ditandai dengan pergerakan operculum yang lambat dan ikan diam di dasar akuarium (Cahyadi, 2009). Satuan percobaan untuk mengukur kecepatan pingsan yaitu menit. Kecepatan pingsan diamati setiap menit

() Copyright by Saintek Perikanan (Indonesian Journal of Fisheries Science and Technology), ISSN : 1858-4748 
selama satu jam, dalam setiap pengamatan diamati perilaku ikan. Setelah sebagian besar pingsan ikan uji dipindahkan, untuk selanjutnya dikemas.

\section{Pengemasan Ikan dan Simulasi Transportasi}

Pengemasan dilakukan dalam kotak styrofoam. Hancuran es $(0,5 \mathrm{~kg})$ yang dibungkus kantung plastik diletakkan di dasar kemudian ditutup dengan kertas koran. Serbuk gergaji lembab dingin $\left(18^{\circ} \mathrm{C}\right)$ dihamparkan di atas kertas koran dengan ketebalan $7 \mathrm{~cm}$, kemudian di atas hamparan serbuk gergaji diletakkan benih ikan nila yang sudah dianestesi berderet rapi, benih ikan nila merah terlebih dahulu dikemas kedalam pelastik yang diberi sedikit air bersih didalamnya dan diikat karet dibagian atasnya (15 ekor perkemasan). Di atas ikan dihamparkan kembali media serbuk gergaji lembab dingin setebal sekitar $5 \mathrm{~cm}$, kemudian kotak styrofoam ditutup rapat dan diberi selotip agar suhu di dalam media konstan.

\section{Pengamatan Pulih Sadar}

1. Menyiapkan akuarium sebanyak 9 buah, bersihkan, dan diisi air sebanyak 151 kemudian diaerasi.

2. Setelah waktu simulasi selesai dilakukan, benih nila merah diambil kemudian dimasukan ke dalam akuarium sesuai label perlakuan waktu yang telah ditentukan dan diamati sampai benih sadar kembali sebagai indikator benih nila merah bergerak aktif.

3. Kemudian waktu pulih sadar dan survival rate benih nila merah diamati dan dicatat.

4. Pencatatan waktu pulih sadar ikan dicatat per individu benih ikan disetiap perlakuan.

\section{Pemeliharaan Benih}

1. Akuarium disiapkan sebanyak 9 buah dan diisi air sebanyak 151 yang telah diaerasi selama 48 jam.

2. Benih nila merah dimasukkan ke dalam akuarium dan dipelihara selama 10 hari serta diberi pakan komersial secara at satiation 2 kali sehari yaitu pukul 08.00 dan pukul 16.00 WIB.

3. Penyiponan dilakukan setiap hari dan dilakukan pergantian air selama 3 hari sekali.

4. Setelah 10 hari pemeliharaan, dilakukan penimbangan berat benih ikan dan pengamatan kelangsungan hidup benih nila merah.

\section{Kelangsungan Hidup Uji Simulasi Transportasi dan Pemeliharaan}

Kelangsungan hidup uji simulasi yaitu nilai ikan yang hidup pada pengujian setelah dilakukan uji simulasi transportasi. Kelangsungan hidup pemeliharaan adalah nilai dari perbandingan antara jumlah ikan yang hidup sampai akhir pemeliharaan, dengan jumlah awal ikan saat dipelihara. Menurut Effendi (1997), untuk menghitung Survival rate (SR) dapat digunakan rumus :

$$
\mathrm{SR}=\frac{\mathrm{Nt}}{\mathrm{No}} 100 \%
$$

Keterangan :

SR : Derajat kelangsungan hidup (\%)

Nt : Jumlah ikan akhir (ekor)

$\mathrm{N}_{0}$ : Jumlah ikan awal (ekor)

\section{Laju pertumbuhan mutlak}

Laju pertumbuhan mutlak (Growth rate) adalah pertumbuhan berat benih nila merah setiap harinya selama pemeliharaan. Menurut Effendi (1997), laju pertumbuhan mutlak dapat dinyatakan dengan rumus :

$$
\mathrm{GR}=\frac{W \mathrm{t}-W_{0}}{\mathrm{t}}
$$

Keterangan :

GR : Growth rate (g/hari)

Wt : Berat rata-rata akhir $(\mathrm{g})$

Wo : Berat rata-rata awal (g)

t : Lama pemeliharaan (hari)

\section{Pengamatan Parameter Kualitas Air}

Parameter kualitas air yang diamati yaitu $\mathrm{pH}(\mathrm{pH}$ meter), suhu (Thermometer), dan Oksigen terlarut (DO meter). Pengamatan dilakukan setiap hari dimulai pada pukul 06.00 WIB sampai dengan selesai.

Parameter penentuan ikan pingsan mengacu pada: Perlakuan yang digunakan untuk uji simulasi transportasi adalah lama waktu transportasi yaitu 1, 2, dan 3 jam; perlakuan konsentrasi efektif ekstrak bunga kenanga yaitu 61,40 ppm dan diulang sebanyak 3 kali ulangan. Parameter yang digunakan adalah kelangsungan hidup dan pertumbuhan benih nila merah.

Analisis data pengaruh waktu transportasi dan konsentrasi efektif terhadap kelangsungan hidup benih ikan nila merah menggunakan rancangan acak lengkap (RAL) dengan selang kepercayaan 95\% tanpa kontrol, dan 3 kali ulangan.

\section{HASIL DAN PEMBAHASAN}

\section{Uji Pendahuluan}

Konsentrasi yang digunakan untuk uji pendahuluan adalah 0,$01 ; 0,1 ; 1 ; 10$ dan 100 ppm. Tujuan uji pendahuluan ini adalah untuk menentukan ambang batas atas dan bawah. Rentang konsentasi yang didapat yaitu 100 ppm sebagai ambang batas atas, dan 10 ppm sebagai ambang batas bawah. Ambang batas atas yaitu konsentrasi terendah dari bahan uji yang menyebabkan semua ikan uji mati setelah pemaparan 24 jam. Sedangkan ambang batas bawah merupakan konsentrasi tertinggi dari bahan uji yang menyebabkan semua ikan uji hidup setelah pemaparan 48 jam.

Kisaran 10-100 ppm didapat karena saat akhir pengamatan pada konsentrasi 10 ppm ikan hidup semua sampai akhir pengamatan dan pada konsentrasi 100 ppm ikan yang diuji mati semua. Hasil ini cukup baik karena semakin kecil rentang konsentrasi maka semakin toksik pada bahan aktif tersebut (Cahyadi, 2009).

Deret konsentrasi untuk uji utama ditentukan dari nilai ambang batas atas dan ambang batas bawah (10 - 100 ppm). Berdasarkan hasil pengujian ambang atas dan ambang bawah, didapat dosis perlakuan yaitu 15,85 ppm, 25,12 ppm, 39,82 ppm, 63,11 ppm, dan 100,03 ppm.

\section{Uji Utama}

Berdasarkan hasil penentuan deret konsentrasi untuk uji utama dapat dilihat pada Tabel 1. 
Tabel 1.Jumlah Mortalitas Benih Ikan Nila pada Uji Utama (96 Jam)

\begin{tabular}{cc}
\hline Konsentrasi & $\begin{array}{c}\text { Mortalitas Benih Nila } \\
\text { Merah }\end{array}$ \\
\hline $\mathbf{1 5 , 8 5}$ & - \\
$\mathbf{2 5 , 1 2 2}$ & - \\
39,818 & - \\
63,111 & - \\
100,030 & $100 \%$ \\
\hline
\end{tabular}

Hasil pengujian memperlihatkan bahwa konsentrasi ekstrak tertinggi yaitu sebesar $100,030 \mathrm{ppm}$ saja yang menghasilkan respon kematian diatas $50 \%$ dalam waktu terendah 48 jam dan $100 \%$ dalam waktu 96 jam. Dari hasil tersebut terlihat adanya kecenderungan yaitu dengan semakin tingginya konsentrasi akan memberikan respon kematian yang lebih besar. Berikut adalah hubungan antara Log $(\mathrm{K})$ dengan Probit Mortalitas LC $50-96$ jam (Gambar 1).

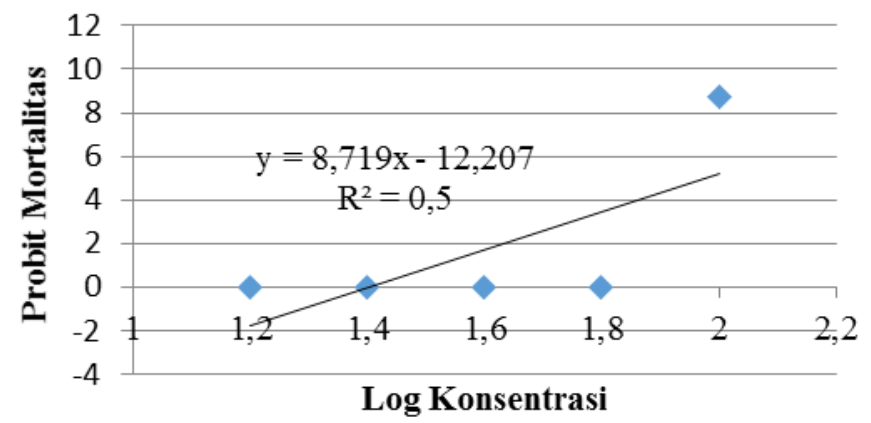

Gambar 1. Hubungan antara Log (K) dengan Probit Mortalitas Untuk Menentukan $\mathrm{LC}_{50}-96$ jam

Tingginya tingkat mortalitas dikarenakan bereaksinya senyawa aktif pada eksatak bunga kenanga yaitu senyawa aktif eugenol selama waktu pengamatan 96 jam. Senyawa aktif eugenol yang terkandung dalam bunga kenanga mempunyai sifat sebagai stimulan dan anastesi lokal (Nurdjanah, 1997).

Hasil penelitian selama waktu pengamatan 96 jam kemudian dianalisis dengan menggunakan analisa probit. Penggunaan analisa probit dimaksudkan untuk menyederhanakan perhitungan, dimana nilai persentase kematian diubah dalam nilai probit (probit $=$ probability peluang) dengan menggunakan tabel transformasi probit dan konsentrasi/dosis dinyatakan sebagai nilai logaritmanya (Hendri $d k k, 2010)$.

Nilai $\mathrm{LC}_{50}-96$ jam yang di dapat dari analisis probit pada penelitian ini yaitu 93,97 ppm dan selama waktu pengamatan hanya konsentrasi paling tinggi yang menyebabkan semua ikan mati. Pada konsentrasi 63,111 ppm atau konsentrasi tertinggi ke dua terlihat ada pengaruh bahan uji pada ikan, tetapi pada konsentrasi tersebut tidak dapat membuat ikan mati hanya pingsan dan beberapa saat kemudian ikan kembali pulih. Adanya aerasi yang dapat mengurangi pengaruh senyawa toksik tersebut (Hinson, 2000).

Percepatan laju kematian benih ikan uji disebabkan oleh pemberian konsentrasi yang tinggi, semakin tinggi konsentrasi maka semakin cepat proses penyerapan zat anestesi oleh darah yang kemudian akan menyebar ke seluruh bagian tubuh benih ikan, sehingga ikan uji akan cepat mengalami kematian dalam waktu pengamatan 96 jam tersebut.
Senyawa aktif eugenol yang terdapat pada bahan anestesi yang larut dalam air akan mengakibatkan berkurangnya laju respirasi pada benih ikan. Kondisi tersebut menyebabkan benih ikan gelisah kemudian selalu berupaya untuk naik ke permukaan untuk mendapatkan oksigen. Penurunan laju respirasi tersebut menyebabkan hilangnya seluruh rasa pada bagian tubuh ikan sebagai akibat dari penurunan fungsi syaraf sehingga menghalangi aksi dan hantaran impuls syaraf (Yanto, 2009).

\section{Penentuan ( $\mathrm{EC}_{50}-1$ jam $)$}

Uji penentuan nilai konsentrasi efektif menunjukan bahwa semakin tinggi konsetrasi bahan anestesi yang diberikan pada ikan uji maka akan semakin banyak jumlah ikan yang pingsan (Tabel 2).

Tabel 2 Uji penentuan nilai konsentrasi efektif ( $\left.\mathrm{EC}_{50}-1 \mathrm{jam}\right)$

\begin{tabular}{cc}
\hline Konsentrasi & $\begin{array}{c}\text { Rata-rata Ikan Uji } \\
\text { Pingsan }\end{array}$ \\
\hline $\mathbf{1 5 , 8 5}$ & - \\
$\mathbf{2 5 , 1 2 2}$ & - \\
39,818 & - \\
63,111 & $60 \%$ \\
100,030 & $100 \%$ \\
\hline
\end{tabular}

Menurut Abdullah (2012), menyatakan bahwa pada konsentrasi pemberian bahan anestesi yang lebih tinggi, menyebabkan ikan mengalami pingsan lebih cepat dan jumlah ikan yang pingsan lebih banyak. hal tersebut (Tabel 2) diduga karena bahan anestesi yang diserap oleh ikan uji berbeda dari setiap konsentrasi yang diberikan.

Hasil penelitian selama waktu pengamatan 1 jam kemudian dianalisis dengan menggunakan analisa probit Penggunaan analisa probit dimaksudkan untuk menyederhanakan perhitungan (Hendri dkk, 2010). Nilai konsentrasi efektif ( $\left.\mathrm{EC}_{50}-1 \mathrm{jam}\right)$ ekstrak bunga kenanga yang didapat dengan menggunakan analisis probit yaitu 61,40 ppm.

Analisis probit konsentrasi efektif $\left(\mathrm{EC}_{50}-1\right.$ jam $)$ dilakukan untuk mengetahui konsentrasi perlakuan yang menyebabkan ikan pingsan, sehingga dapat ditentukan konsentrasi perlakuan yang aman untuk anestesi pada uji transportasi. Hasil tersebut menunjukan bahwa ekstrak bunga kenanga dengan konsentrasi 61,40 ppm hanya membuat ikan uji pingsan. Senyawa aktif eugenol yang terdapat pada bahan anestesi yang larut dalam air akan mengakibatkan berkurangnya laju respirasi pada benih ikan. Menurut Nurdjanah, (1997), menyatakan bahwa senyawa aktif eugenol yang terkandung dalam bunga kenanga mempunyai sifat sebagai stimulan dan anastesi lokal. Pada saat proses anestesi menggunakan nilai konsentrasi efektif $\left(\mathrm{EC}_{50}-1 \mathrm{Jam}\right)$ dilakukan pengamatan kecepatan pingsan dan tingkah laku ikan uji.

Tabel 3 Tingkah laku dan kecepatan pingsan ikan uji selama anestesi

\begin{tabular}{ccl}
\hline Dosis & $\begin{array}{c}\text { Waktu } \\
(\text { menit ke) }\end{array}$ & \multicolumn{1}{c}{ Tingkah laku ikan } \\
\hline $\begin{array}{c}61,40 \\
\text { ppm }\end{array}$ & $1-10$ & $\begin{array}{l}\text { Normal } \\
\text { Mulai kehilangan keseimbangan, } \\
\text { sebagian pingsan } \\
\text { Sebagian besar pingsan, kurang } \\
\text { merespon rangsangan dari luar }\end{array}$ \\
\hline
\end{tabular}


Kecepatan pingsan benih nila merah dengan dosis 61,40 ppm adalah 10-15 menit. Kecepatan pingsan tersebut masih belum ideal sebagai bahan anestesi, sesuai dengan pernyataan Aini $d k k$. (2014), bahwa bahan anestesi dikatakan ideal jika mampu membuat ikan pingsan dalam waktu 3 menit. Tetapi hasil tersebut masih lebih cepat jika dibandingkan dengan aplikasi anestesi pada lobster air tawar yang mencapai 135-150 menit (Suryaningrum $d k k, 2005$ ).. Perbedaan waktu kecepatan pingsan diduga karena kemampuan organisme yang berbeda dalam menyerap bahan anestesi yang ada pada lingkungan. Perbedaan bahan anestesi dan penggunaan konsentrasi juga diduga berpengaruh terhadap kecepatan pingsan organisme pada saat penelitian.

\section{Uji Simulasi Transportasi}

Uji Simulasi transportasi dilakukan dengan menggunakan kendaraan roda dua (motor), dengan asumsi bahwa jarak tempuh dihitung sama dengan waktu transportasi saat dalam perjalanan seminimal mungkin. Simulasi transportasi dilakukan selama tiga waktu pengamatan yaitu 1, 2 , dan 3 jam. Ikan yang telah dianestesi menggunakan ekstrak bunga kenanga pada waktu yang berbeda dengan dosis 61,40 ppm, langsung dikemas kedalam media pengiriman segera setelah ikan pingsan. Proses simulasi transportasi dilaksanakan di Bandar Lampung, yakni dari Laboratorium Budidaya Perairan hinga keliling daerah Bandar Lampung dan kembali lagi ke Laboratorium Budidaya Perairan untuk pengamatan pulih sadar

\section{Pulih Sadar}

Waktu pulih sadar benih nila merah tercepat terjadi pada konsentrasi yang digunakan pada waktu transportasi 1 jam yaitu dengan waktu 1,20 menit. Pada waktu transportasi 2 jam membutuhkan waktu 2,50 menit, dan Pada perlakuan transportasi 3 jam membutuhkan waktu 3 menit untuk ikan uji pulih sadar. Lama waktu pulih sadar hewan uji pada perlakuan waktu 2, dan 3 jam lebih lama jika dibandingkan perlakuan waktu 1 jam. Perbedaan waktu pulih sadar tersebut diduga disebabkan masih adanya pengaruh bahan anestesi yang diberikan pada setiap perlakuan lama waktu transportasi yang dilakukan. Menurut Achmadi (2005), ikan-ikan dengan ruang insang yang besar lebih cepat dan efisien dalam menyerap bahan-bahan anaestesi. Disamping itu, ukuran tubuh, aktivitas, ikan yang sehat, umur dan jenis kelamin juga mempengaruhi kecepatan induksi bahan anaestesi dan proses pulih sadarnya.

Faktor-faktor yang mempengaruhi kecepatan induksi dan proses kecepatan pulih sadar dapat diabaikan karena hanya menggunakan satu spesies dengan ukuran yang sama. Uji simulasi transportasi benih nila merah selama 1, 2, dan 3 jam menunjukan bahwa, perlakuan waktu transportasi dengan kelangsungan hidup terbesar terdapat pada perlakuan 1 jam dengan nilai rata-rata seluruhnya $91,1 \%$, kelangsungan hidup pada perlakuan 2 jam sebesar 73,3\%, sedangkan kelangsungan hidup pada perlakuan 3 jam memiliki nialai paling rendah yaitu sebesar 62,2\% (Gambar 2). Perbedaan perlakuan waktu transportasi berpengaruh nyata terhadap kelangsungan hidup benih nila merah pada uji transportasi tanpa media air. Hal tersebut dapat dilihat pada Gambar 2, yang menunjukan nilai tertinggi terdapat pada perlakuan 1 jam dengan nilai rata-rata seluruhnya 91,1\%. Kelangsungan hidup ikan uji semakin menurun seiring bertambahnya waktu transportasi yang dilakukan, hal tersebut dapat dilihat pada perlakuan waktu transportasi 2, dan 3 jam yang semakin menurun. Faktor penyebab turunnya nilai kelangsungan hidup benih nila merah tersebut diduga karena terjadi penurunan kualitas ai $\mathrm{r}$ dalam media pengiriman, yang memungkinkan terjadi yaitu kenaikan suhu sehingga menyebabkan metabolisme ikan meningkat. Aktivitas ikan yang semakin tinggi di dalam media pengiriman membuat kebutuhan oksigen ikan pun bertambah, sehingga ikan mengalami kekurangan oksigen dan berakibat kematian.

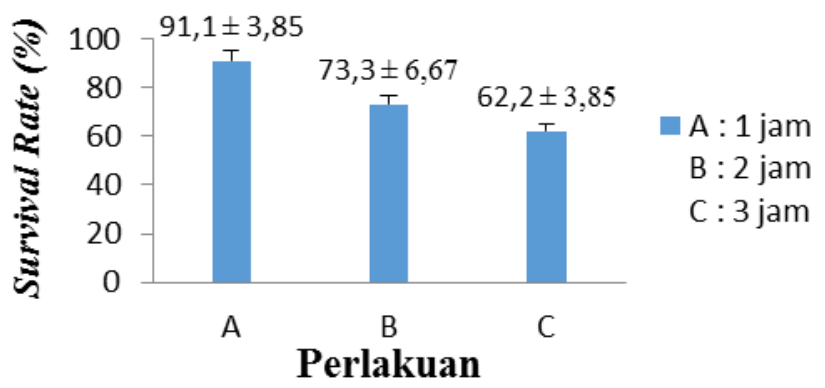

Gambar 2. Survival Rate Simulasi Transportasi

Oksigen yang dibutuhkan ikan hanya sedikit ketersediaannya pada media pengiriman sistem kering atau tanpa media air tersebut. Sistem pengiriman tanpa media air membuat difusi oksigen tidak dapat terjadi dikarenakan kurangnya air pada media pengiriman yang digunakan pada penelitian ini. Semakin lama waktu transportasi, maka oksigen dalam media pengiriman semakin berkurang. Ikan yang mengalami kekurangan oksigen dapat menyebabkan kematian (Karnila, 2001). Hal tersebut menunjukan bahwa perbedaan waktu transportasi berpengaruh terhadap kelangsunagn hidup ikan uji.

\section{Pemeliharaan Benih Nila Merah}

Setelah proses anestesi dengan dosis 61,40 ppm dan simulasi transportasi selesai dilakukan. Selanjutnya benih nila merah yang telah melalui proses pulih sadar dipeliharaa selama 10 hari untuk mengetahui kelangsungan hidup pemeliharaan dan pertumbuhan. Nilai kelangsungan hidup rata-rata tertinggi terjadi pada perlakuan transportasi 1 jam, yaitu $63,4 \%$. Sedangkan nilai kelangsungan hidup rata-rata terendah terjadi pada perlakuan transportasi 3 jam, yaitu 53,7\%, dan pada perlakuan transportasi 2 jam nilai rata-rata kelangsungan hidupnya yaitu 54,3\% Tabel 4.

Tabel 4. Survival Rate Pemeliharaan

\begin{tabular}{ccccc}
\hline Perlakuan & \multicolumn{3}{c}{ Jumlah Ikan Uji (ekor) } & \multirow{2}{*}{$\begin{array}{c}\text { SR } \\
\end{array}$} \\
\cline { 2 - 4 } & Awal & Akhir & Kematian & $(\%)$ \\
\hline 1 Jam & 41 & 26 & 15 & 63,4 \\
2 Jam & 33 & 18 & 15 & 54,3 \\
3 Jam & 28 & 15 & 13 & 53,7 \\
\hline
\end{tabular}

Nilai kelangsungan hidup (survival rate) ikan uji setelah pemeliharaan selama 10 hari menunjukan nilai tertinggi yaitu pada perlakuan waktu transportasi 1 jam mencapai $63,4 \%$, dan terendah pada perlakuan waktu transportasi 3 jam yaitu sebesar 53,7 \%. Namun yang paling banyak mengalami kematian yaitu pada perlakuan waktu transportasi 1 dan 2 jam yakni masing-masing berjumalah 16 ekor, sedangkan pada perlakuan waktu transportasi 3 jam hanya 13 ekor ikan yang mengalami kematian. Total ikan yang mengalami kematian

(C) Copyright by Saintek Perikanan (Indonesian Journal of Fisheries Science and Technology), ISSN : 1858-4748 
setelah pemeliharan selama 10 hari adalah 45 ekor yang tersebar pada perlakuan waktu transportasi.

Kematian ikan di akuarium pemeliharaan sebagian besar terjadi pada awal pemeliharaan. Adaptsi ikan terhadap perubahan lingkungan dari kemasan kedalam akuarium membuat ikan banyak mati di awal pemeliharaan. Kemungkinan proses osmoregulasi sebagai sarana untuk membuang zat-zat yang tidak diperlukan (zat anestesi) oleh sel atau organisme hidup tidak berjalan dengan baik (Fujaya, 2004). Rendahnya tingkat kematian ikan terjadi setelah beberapa hari pemeliharaan ketika kualitas air pada media pemeliharaan tergolong cukup layak untuk kelangsungan hidup dan pertumbuhan ikan uji.

Faktor penyebab kematian ikan saat pemeliharaan diduga akibat rendahnya kemampuan adaptasi masing-masing ikan ketika berada di lingkungan yang baru. Pengelolaan kualitas air telah dilakukan untuk menjaga kualitas air pemeliharaan agar tetap berada pada kondisi optimal, namun beberapa ikan tidak mampu beradaptasi terhadap lingkungan sehingga benih nila merah mengalami kematian. Hal tersebut menunjukan bahwa masih adanya pengaruh bahan anestesi didalam tubuh ikan yang belum sepenuhnya hilang.

\section{Laju Pertumbuhan Mutlak}

Benih ikan yang telah dipelihara selama 10 hari dihitung laju pertumbuhannya. Hal tersebut dilakukan untuk mengetahui pengaruh ekstrak bunga kenanga terhadap pertumbuhan (Gambar 3).

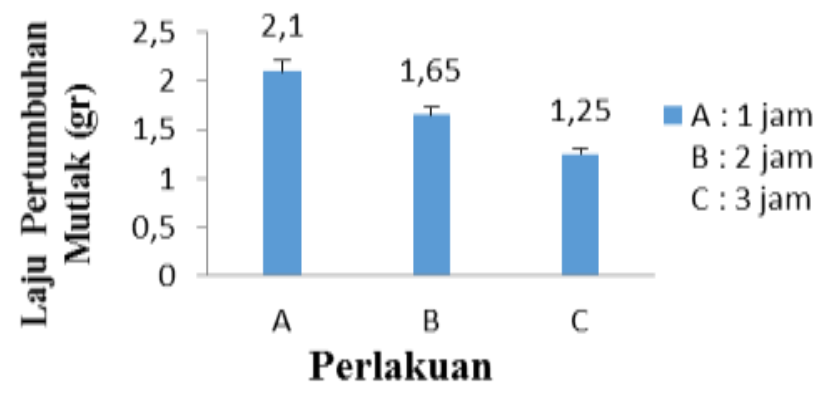

Gambar 3. Hasil pengamatan pertumbuhan mutlak rata-rata benih nila merah

Hasil pengamatan terhadap laju pertumbuhan mutlak benih nila merah setelah dilakukan transportasi dan pemeliharaan menunjukan bahwa laju pertumbuhan mutlak rata-rata tertinggi terjadi pada perlakuan waktu transportasi 1 jam yaitu 2,1 gr, sedangkan laju pertumbuhan mutlak rata-rata terendah terjadi pada perlakuan waktu transportasi 3 jam yaitu 1,25 gr, dan pada perlakuan waktu transportasi 2 jam hasilnya yaitu 1,65 gr (Gambar 2).

Faktor penyebab perbedaan nilai atau hasil dari pengamatan laju pertumbuhan mutlak disebabkan, benih ikan sebelum dilakukan pemeliharaan pada setiap perlakuannya berbeda-beda tidak sama rata, sehingga hasil yang didapat disaat pengamatan pertumbuhan mutlak akan tetap berbeda pada setiap perlakuannya. Jika jumlah ikan yang dipelihara pada setiap perlakuan sama rata maka hasil yang didapat pada saat pengamatan pertumbuhan mutlak kemungkinan akan relatif sama hasilnya.

Menurut Effendie (1997), pertumbuhan dipengaruhi oleh faktor internal dan eksternal. Faktor internal sebagian besar tergantung pada kondisi tubuh ikan tersebut, misalnya kemampuan ikan dalam memanfaatkan sisa energi dan protein setelah metabolisme untuk pertumbuhannya. Sedangkan, faktor eksternal seperti faktor lingkungan dan pakan sangat berpengaruh pada pertumbuhan ikan. Kedua faktor tersebut akan menyeimbangkan keadaan tubuh ikan selama dalam media pemeliharaan dan menunjang pertumbuhan tubuh benih ikan nila.

Hasil pengamatan terhadap laju pertumbuhan mutlak benih nila merah setelah dilakukan transportasi dan pemeliharaan selama 10 hari berkisar antara 1,8-1,87 gr. Hal tersebut menunjukan tidak ada perbedaan antara pertumbuhan ikan yang diberikan bahan anestesi pada setiap perlakuan lama waktu transportasi yang dilakukan. Hal tersebut diduga bahan anestesi yang masuk kedalam tubuh ikan telah hilang dan tidak residu dan tidak berbahaya bagi tubuh ikan (Darmono, 2014; Pramono, 2002), sehingga ikan mampu hidup dengan kondisi organ dan pencernaan yang normal. Selama pemeliharaan dilakukan pengamatan kualitas air pemeliharaan. Hasil pengamatan kualitas air selama pemeliharaan tersaji pada Tabel 5 .

$\underline{\text { Tabel 5. Kisaran Kualitas Air Pemeliharaan Benih Nila Merah }}$

\begin{tabular}{lcc}
\hline \multicolumn{1}{c}{ Parameter } & Kisaran & Optimal* \\
\hline Suhu $\left({ }^{\circ} \mathrm{C}\right)$ & $25-26$ & $25-30$ \\
$\mathrm{Ph}$ & $6,5-6,7$ & $6-8$ \\
Oksigen terlarut $(\mathrm{mg} / \mathrm{l})$ & $5,1-6,8$ & $4-6$ \\
\hline
\end{tabular}

*Sumber : Effendi, 2003

Berdasarkan hasil pengamatan menunjukan bahwa, kualitas air media pemeliharaan untuk seluruh parameter relatif masih berada pada tarap yang optimal bagi ikan. Suhu media pemeliharaan ikan berada pada kisaran $25-26^{\circ} \mathrm{C}$, hal itu berada pada traf optimal yaitu $25-30^{\circ} \mathrm{C}$. $\mathrm{pH}$ media berada pada kisaran 6,5-6,7 hal tersebut berada pada taraf optimal yaitu 6-8. Kisaran oksigen terlarut pada media berada pada taraf diatas optimal, hal tersebut menunjukan ketersediaan oksigen untuk pemeliharaan sangat cukup. Kualitas air yang berada pada taraf optimal sehingga mendukung dalam rangka pemeliharaan ikan, hal tersebut memungkinkan ikan dapat hidup dan berkembang dengan baik.

\section{KESIMPULAN}

Berdasarkan hasil penelitian dapat disimpulkan bahwa hasil perhitungan yang didapat dengan menggunakan analisis probit nilai konsentrasi efektif ekstrak bunga kenanga untuk pemingsanan pada uji simulasi transportasi yang aman yaitu 61,40 ppm hanya membuat benih ikan nila merah ukuran 3-5 cm pingsan.

Survival rate transportasi benih nila merah tertinggi mencapai 91,1 \%. Perbedaan perlakuan waktu transportasi berpengaruh nyata terhadap kelangsungan hidup (SR) benih nila merah pada uji transportasi tanpa media air setelah dipingsankan dengan konsentrasi ekstrak bunga kenanga 61,40 ppm.

\section{UCAPAN TERIMA KASIH}

Ucapan terima kasih penulis sampaikan kepada dosen pembimbing dan pembahas yang telah memberikan saran untuk perbaikan artikel ini dan semua pihak yang telah membantu dalam penyelesaian artikel ini. Penulis juga mengucapkan terima kasih kepada tim editor jurnal saintek 
FPIK Undip atas saran dan revisi sehingga naskah ini layak untuk dipublikasikan.

\section{DAFTAR PUSTAKA}

Abdullah, R. R. 2012. Teknik Imotilisasi Menggunakan Hati Batang Pisang (Musa Spp) dalam Simulasi Transportasi Kering Ikan Bawal Air Tawar (Colossoma macropomum). Scientific Repository. Bogor Agricultural University. http://repository.ipb.ac.id. Diakses Tanggal 20 Maret 2017

Cahyadi. R. 2009. Uji Toksisitas Akut Ekstrak Etanol Buah Pare (Momordica charantia L.) Terhadap Larva Artemia Salina Leach Dengan Metode Brine Shrimp Lethality Test (BSLT). Laporan Akhir Karya Ilmiah. Fakultas Kedokteran. Universitas Diponegoro. Semarang

Darmono. 2014. Teknik Alkohol. Artikel Ilmiah. http://www.geocities.wk. diakses tanggal 11 juli 2014 pukul 11.36 WIB

Effendi, H. 2003. Telaah Kualitas Air: Bagi Pengelolaan Sumberdaya dan Lingkungan Perairan. Gramedia. Jakarta. 257

Effendie, M I. 1997. Metode Biologi Perikanan. Bogor: Yayasan Dwi Sri.

Fujaya, Y. 2004. Fisiologi Ikan Dasar Pengembangan Teknik Perikanan. Cetakan pertama. Rineka Putra. Jakarta.

Hinson, D. 2000. Rotenone Characterixation and Toxicity in Aquatic System. Principles of Enviromental Toxicology. Idaho 1-13

Hendri, M., Gusti, G., dan Jetun, T. 2010. Konsentrasi Letal $\left(\mathrm{LC}_{50}-48\right.$ jam) Logam Tembaga $(\mathrm{Cu})$ dan Logam
Kadmium (Cd) Terhadap Tingkat Mortalitas Juwana Kuda Laut (Hippocampus spp). Jurnal Penelitian Sains. Vol. 13 No. 1 : 26-30

Irawan, O.R., 2014. Uji Toksisitas Akar Tuba (Derris elliptica) dengan Pelarut Yang Berbeda Terhadap Benih Ikan Mas (Cyprinus carpio). Skripsi. Universitas Lampung. Bandar Lampung

Karnila, R.E. 2001. Pengaruh Waktu dan Suhu Pembiusan Bertahap Terhadap ketahanan hidup Ikan jambal siam (Pangasius sutchi) dalam Transportasi Sistem Kering. Jurnal Natur Indonesia III(2): 151-167. Fakultas Perikanan dan Ilmu Kelautan Universitas Riau.

Moelyono, M. W., Yasmiwar, S., T., dan Marina. 2007. Analisis Minyak Atsiri Bunga Kenanga (Cananga odorata Hook.F \& TH). Jurnal Farmaka Vol 5 No. 1. 6-10

Nurdjanah, 1997. Diversifikasi Penggunaan Cengkeh. Balai Besar Penelitian dan Pengembangan Pasca Panen Pertanian. Jakarta.

Pramono, V. 2002. Penggunaan Ekstrak (Caulerpa racemosa) sebagai Bahan Pembius pada Transportasi Ikan Nila (Oreochromis niloticus) Hidup Skripsi. Departemen Teknologi Hasil Perikanan. Institut Pertanian Bogor, Bogor.

Suryaningrum, T. D., Utomo, B. S. B. Wibowo, S. 2005. Teknologi Penanganan dan Transportasi Crustasea Hidup. Pusat Riset Pengolahan Produk dan Sosial ekonomi Kelautan dan Perikanan. Jakarta Pusat.

Yanto, H. 2009. Penggunaan MS-222 dan Larutan Garam pada Transportasi Ikan Jelawat (Leptobarbus hoevenii). Jurnal Ilmu-ilmu Perairan dan Perikanan Indonesia. (16)1: 47-54. 